http://jmscr.igmpublication.org/home/ ISSN (e)-2347-176x ISSN (p) 2455-0450 crossref DOI: https://dx.doi.org/10.18535/jmscr/v9i6.19

\title{
Study on Knowledge \& Awareness of COVID-19 among Undergraduates of G.S.V.M Medical College Kanpur
}

\author{
Authors \\ Chaudhary Pankaj ${ }^{1}$, Nigam Seema ${ }^{2}$ \\ Department of Community Medicine, GSVM Medical College Kanpur
}

\begin{abstract}
Background: COVID-19 is an abbreviation for Coronavirus disease 2019 since its first detection in China it has now spread all over the world, with reports of local transmission happening in more than 200 countries. A series of measures have been suggested to reduce COVID-19 infection, including knowledge \& awareness for prevention and control.

Objective: To assess the knowledge \& awareness regarding COVID-19 among undergraduates.

Methodology: A Crossectional study was conducted among the undergraduate of GSVM Medical College Kanpur from $1^{\text {st }}$ November 2020 to $15^{\text {th }}$ December 2020. A total of 182 undergraduate students who consented to the study were included.

Results: The majority 99.4\% knew about the COVID-19 pandemic, $81.3 \%$ of participants uses Aarogya Setu applications for online tracking awareness, $96.7 \%$ wash their hand regularly and $90.1 \%$ of participants wear a mask to avoid transmission.

Conclusions: Our study showed that the undergraduates had good knowledge, awareness, and sensible prevention measures regarding COVID-19 infection.

Keywords: knowledge, awareness, COVID-19.
\end{abstract}

\section{Introduction}

In late December 2019, an investigation of a cluster of pneumonia cases of unknown origin in Wuhan, China resulted in the identification of a novel coronavirus. The virus is distinct from both severe acute respiratory syndrome (SARS) coronavirus and Middle East Respiratory Syndrome (MERS) coronavirus, although closely related. The disease since its first detection in China has now spread to over 200 countries/territories. COVID-19 was declared a Pandemic by WHO on 11th March 2020 resulting in the shift of focus from China to Europe and North America and later on to the world. As such
WHO advised countries to take a whole-ofgovernment, whole-of-society approach, built around a comprehensive strategy to prevent disease, save lives and minimize the effect. Countries closed their borders against travelrelated activities (by air, road, railway, or sea), and a lockdown was imposed to minimize the public movements. In India, the first case of COVID-19 was reported on 30h January 2020 in Kerala. India currently has the number largest of confirmed cases in Asia. The per-day cases peaked in mid-September 2020 with about 90,000 reported cases. In India, the outbreak of the disease was declared an epidemic, and Epidemic 
Disease Act, 1897 was invoked leading to the temporary closure of educational, religious, entertainment, and commercial establishments. On 25th March 2020, the Govt. of India declared a country-wide lockdown till 31st March, which was extended up to 14th April 2020. This lockdown was further extended to 3rd May, then up to 17th May 2020. This covers 4 phases of lockdown in the country. It was followed by gradual unlockdown in the country, spread in 6 phases (one month each) up to 30th November 2020. It is estimated that 1.5 billion students were confined at home worldwide due to the closure of schools and universities, thus making education uncertain at all levels. A series of measures have been suggested to reduce COVID-19 infection, including knowledge \& awareness for prevention and control. We conducted this study intending to assess the knowledge \& awareness regarding COVID-19 among undergraduates.

\section{Materials and Methods}

A crossectional study was conducted among the M.B.B.S Final Professional part-1 undergraduates of GSVM Medical College Kanpur from $1^{\text {st }}$ November 2020 to $15^{\text {th }}$ December 2020. A total of 182 undergraduates students who consented to the study were included. 104 boys and 78girls students participated in the study, each student was explained about the study objectives and implications. A predesigned and pretested questionnaire was used to record the information containing relevant questions for achieving the objective of the study. A total set of 20 questions were made mandatory to eliminate the chances of any incomplete responses. Necessary settings limited the number of responses to one per participant which prevented the submission of multiple response forms by a single participant. Data was collected by sharing a questionnaire google form through an online WhatsApp media link among the undergraduates. Data was compiled \& tabulated on google sheet and appropriate statistical tools were applied to analyze the data and results were drawn.

\section{Results}

The cross-sectional study was conducted to ascertain the knowledge and awareness among the 182 study participants. In Table 1 knowledge regarding COVID-19 is described among the participants. The majority $99.4 \%$ knew about the COVID-19 pandemic, $72.5 \%$ knew all ways of transmission and $56.5 \%$ knew about the incubation period. Table 2 shows awareness regarding COVID-19, a total of $48.3 \%$ of participants responded that television was the main source of awareness, $58.2 \%$ \& $51.6 \%$ responded to the government's initiatives and contact authorities respectively. A total of $64 \%$ of respondents followed COVID-19 lockdown advisories rules. $81.3 \%$ of participants use Aarogya Setu applications for online tracking awareness whereas $69.7 \%$ answered for RT-PCR as a confirmatory test for COVID-19. Table 3 reports the awareness of preventive measures, $96.7 \%$ wash their hand regularly and $90.1 \%$ of participants wear a mask to avoid transmission whereas $93.4 \%$ respondents for proper steps of hand washing. Table 4 shows the comparison of awareness for preventive measures toward the COVID-19 among boys and girls, $97.4 \%$ \& $89.7 \%$ girls whereas $96.1 \%$ \& $90.3 \%$ boys students reported for hand washing and wearing mask respectively as preventive measures towards COVID- 19. $30.7 \%$ of girls and $17.3 \%$ of boys students visited shopping malls or markets frequently. The study finds a statistically significant correlation between boys and girls $p$ value $=.0329$ for visiting a shopping mall or markets frequently. 
Table 1: Knowledge of Study Subjects Regarding COVID-19 n (182)

\begin{tabular}{|c|c|c|c|}
\hline & Type of response & Frequency & $\%$ \\
\hline \multicolumn{4}{|l|}{ Known about COVID- 19 pandemic } \\
\hline & Yes & 181 & 99.4 \\
\hline & No & 1 & 0.5 \\
\hline \multicolumn{4}{|l|}{ The first case of COVID-19 reported in India } \\
\hline & Kerala & 139 & 76.3 \\
\hline & New Delhi & 23 & 12.6 \\
\hline & Mumbai & 18 & 9.8 \\
\hline & Ahmedabad & 2 & 1.0 \\
\hline \multicolumn{4}{|l|}{ Coronavirus transmitted through } \\
\hline & Air droplets or aerosols & 27 & 14.8 \\
\hline & Touching a contaminated surface & 12 & 6.5 \\
\hline & $<2 \mathrm{~m}$ distance & 11 & 6.0 \\
\hline & All of the above & 132 & 72.5 \\
\hline \multicolumn{4}{|l|}{ The incubation period of COVID - 19} \\
\hline & $1-14$ days & 103 & 56.5 \\
\hline & $>14$ days & 68 & 37.3 \\
\hline & $7-9$ days & 11 & 6.0 \\
\hline \multicolumn{4}{|l|}{ Treatment for the person suffering from COVID-19 infection } \\
\hline & No treatment & 76 & 41.7 \\
\hline & Home isolation & 72 & 39.5 \\
\hline & Antibiotic drugs & 34 & 18.6 \\
\hline \multicolumn{4}{|l|}{ All infected COVID-19 contact develops symptoms \& sign } \\
\hline & Yes & 107 & 58.7 \\
\hline & No & 75 & 41.2 \\
\hline \multicolumn{4}{|l|}{ Clinical manifestations of COVID-19 } \\
\hline & Fever & 12 & 6.5 \\
\hline & Cough & 16 & 8.7 \\
\hline & Myalgia & 18 & 9.8 \\
\hline & Shortness of breath & 11 & 6.0 \\
\hline & All of the above & 125 & 68.6 \\
\hline
\end{tabular}

Table 2: Awareness of Study Subjects Regarding COVID-19 n (182)

\begin{tabular}{|c|c|c|c|}
\hline & Type of response & Frequency & $\%$ \\
\hline \multicolumn{4}{|l|}{ Sources of awareness regarding COVID-19 } \\
\hline & Newspaper & 32 & 17.5 \\
\hline & Television & 88 & 48.3 \\
\hline & Radio/FM & 12 & 6.5 \\
\hline & Social media & 50 & 27.4 \\
\hline \multicolumn{4}{|l|}{ Aware of the government's initiatives to prevent COVID-19 } \\
\hline & Yes & 106 & 58.2 \\
\hline & No & 76 & 41.7 \\
\hline \multicolumn{4}{|l|}{ Contact authorities for suspect/confirm cases } \\
\hline & Yes & 94 & 51.6 \\
\hline & No & 88 & 48.3 \\
\hline \multicolumn{4}{|l|}{ Government helpline no. For COVID -19 } \\
\hline & Yes & 96 & 52.7 \\
\hline & No & 86 & 47.2 \\
\hline \multicolumn{4}{|l|}{ Lockdown advisories rules } \\
\hline & Yes & 118 & 64.8 \\
\hline & No & 64 & 35.1 \\
\hline \multicolumn{4}{|l|}{ Better for COVID-19 infection suspects } \\
\hline & Home quarantine & 76 & 41.2 \\
\hline & Administrative quarantine & 42 & 23.0 \\
\hline \multirow{2}{*}{\multicolumn{4}{|c|}{ Use of COVID-19 online tracking applications for awareness }} \\
\hline & & & \\
\hline & WORLDOMETER & 13 & 7.1 \\
\hline & COVID19INDIA & 21 & 11.5 \\
\hline & Aarogya Setu & 148 & 81.3 \\
\hline \multicolumn{4}{|l|}{ Confirmatory test for COVID-19 } \\
\hline & Rapid antigen test & 13 & 7.1 \\
\hline & TNAAT & 42 & 23.0 \\
\hline & RT-PCR & 127 & 69.7 \\
\hline
\end{tabular}


Table 3: Awareness for Preventive Measures of Study Subjects toward COVID-19 n (182)

\begin{tabular}{|l|c|c|c|}
\hline & Type of response & Frequency & \% \\
\hline Wash your hands with soap and water regularly & & & \\
\hline \multirow{2}{*}{ Proper steps of handwashing correctly } & Yes & 176 & 96.7 \\
\cline { 2 - 4 } & Sometimes & 06 & 3.29 \\
\hline Wearing a mask to avoid transmission & Yes & 170 & 93.4 \\
\hline & Sometimes & 12 & 6.59 \\
\cline { 2 - 4 } & & & \\
\hline Visiting shopping mall \& markets frequently & Yes & 164 & 90.1 \\
\hline \multirow{2}{*}{ Attended party or public gathering } & Sometimes & 18 & 9.89 \\
\hline & Yes & 42 & 23.0 \\
\cline { 2 - 4 } & No & 140 & 76.9 \\
\cline { 2 - 4 } & & & \\
\hline & Yes & 34 & 18.6 \\
\cline { 2 - 4 } & No & 148 & 81.3 \\
\hline
\end{tabular}

Table 4: Comparison of Awareness For Preventive Measures toward the COVID-19 Among Boys and Girls

\begin{tabular}{|c|c|c|c|c|}
\hline & $\begin{array}{l}\text { Type of } \\
\text { response }\end{array}$ & $\begin{array}{c}\text { Boys } \\
\text { students n } \\
104(\%) \\
\end{array}$ & $\begin{array}{c}\text { Girls } \\
\text { students } \\
\text { n } 78(\%)\end{array}$ & p-value \\
\hline \multicolumn{5}{|l|}{$\begin{array}{l}\text { Wash your hands with soap } \\
\text { and water regularly }\end{array}$} \\
\hline & Yes & $100(96.1)$ & $76(97.4)$ & \multirow[t]{2}{*}{0.229} \\
\hline & Sometimes & $04(3.84)$ & $02(2.56)$ & \\
\hline \multicolumn{5}{|l|}{$\begin{array}{l}\text { Proper steps of handwashing } \\
\text { correctly }\end{array}$} \\
\hline & Yes & $95(91.3)$ & $75(96.1)$ & \multirow[t]{2}{*}{1.672} \\
\hline & Sometimes & $09(8.65)$ & $03(3.84)$ & \\
\hline \multicolumn{5}{|l|}{$\begin{array}{l}\text { Wearing a mask to avoid } \\
\text { transmission }\end{array}$} \\
\hline & Yes & $94(90.3)$ & $70(89.7)$ & \multirow[t]{2}{*}{0.020} \\
\hline & Sometimes & $10(9.61)$ & $08(10.2)$ & \\
\hline \multicolumn{5}{|l|}{$\begin{array}{l}\text { Visiting shopping mall or } \\
\text { markets frequently }\end{array}$} \\
\hline & Yes & $18(17.3)$ & $24(30.7)$ & \multirow[t]{2}{*}{$.0329^{*}$} \\
\hline & No & $86(82.6)$ & $54(69.2)$ & \\
\hline \multicolumn{5}{|l|}{$\begin{array}{llll}\begin{array}{l}\text { Attended party or public } \\
\text { gathering }\end{array} & & \\
\end{array}$} \\
\hline & Yes & $22(21.1)$ & $12(15.3)$ & \multirow[t]{2}{*}{0.1973} \\
\hline & No & $82(78.8)$ & $66(84.6)$ & \\
\hline
\end{tabular}

*Significant $(\mathrm{p} \leq 0.05)$ on applying chi-square test.

\section{Discussion}

In the present study, $99.4 \%$ of the participants knew about COVID-19 and this result is similar to a study conducted in Mangalore where $98.2 \%$ of the respondents knew about the disease. The source of awareness reached participants mostly through television $48.3 \%$ followed by social media $27.4 \%$. All the modes of transmission and clinical manifestation are being explained on every platform, and this was reflected in our study where $72.5 \%$ knew about all modes of transmission \& $68.6 \%$ about clinical manifestation this is similar to findings by the study done in China. $56.5 \%$ of participants responded correctly about the incubation period similar to the study at Mizan Tepi University. In our study, $76.3 \%$ of the respondents knew about the first case of COVID19 reported in India.

In the present study, $58.2 \%$ of participants were aware of the government's initiatives to prevent COVID-19 while $52.7 \%$ about the government helpline. The majority $81.3 \%$ participants used 
AAROGYA SETU applications for online awareness information for COVID-19 in other studies conducted in Jammu \& Kashmir 26.7\% respondents for WORLDOMETER, while $64.8 \%$ had proper awareness about lockdown advisories rules and $69.7 \%$ about the confirmatory test. Nearly $52.7 \%$ of participants respondent correctly to the government helpline for COVID-19 similar to a study conducted in Jammu \& Kashmir where $51.8 \%$ were aware of helpline no. Around 58.7\% of the respondents knew that all infected COVID19 suspects develop symptoms \& signs, much like a study conducted in Bangladesh. 41.7\% agreed that there was no treatment, and $37.3 \%$ knew about the incubation period as more than 14 days and his results are similar to a study in the USA where participants knew about $39.8 \%$ and $34.8 \%$, respectively. The steps that one would take in case of COVID-19 infection suspects included the following: $41.2 \%$ staying on home quarantine, $35.1 \%$ opting for isolation; and $23.0 \%$ preferring for administrative quarantine.

In our study, $96.7 \%$ and $90.1 \%$ respondents had looked for washing hands regularly and wearing the mask, whereas only $18.6 \%$ for attending the party or public gathering as awareness for prevention towards COVID-19. In the present study, $90.3 \%$ of boys and almost similar $89.7 \%$ of girls responded for wearing a mask to avoid transmission followed by $97.4 \%$ girls $\& 96.1 \%$ boys for proper hand washing.

\section{Acknowledgments}

I would like to acknowledge the study participants for their cooperation and faculty members and residents of the Community Medicine Department of GSVM Medical College for their support and appreciation.

Financial Support and Sponsorship: Nil

Conflicts of Interest: There are no conflicts of interest.

\section{References}

1. McFadden SM, Malik AA, Aguolu OG, Willebrand KS, Omer SB. Perceptions of the adult US population regarding the novel coronavirus outbreak. PLoS One 2020;15:e0231808.

2. Rapid Perception Survey on COVID19 Awareness and Economic Impact. BRACE; 2020.

3. Geldsetzer P. Use of rapid online surveys to assess people's perceptions during infectious disease outbreaks: A crosssectional survey on COVID-19. J Med Internet Res 2020;22:e18790.

4. Wolf MS, Serper M, Opsasnick L, et al. Awareness, Attitudes, and Actions Related to COVID-19 Among Adults With Chronic Conditions at the Onset of the U.S. Outbreak: A Cross-sectional Survey [published online ahead of print, 2020 Apr 9]. Ann Intern Med 2020; M201239. doi:10.7326/M20-1239.

5. Dkhar, et al.: Knowledge, attitude and practices among social media users on COVID-19. IJPH_469_20.

6. Shailaja, et al.: COVID-19 pandemic effect on medical undergraduates. Industrial Psychiatry Journal 117_20.

7. Sahi PK, Mishra D, Singh T. Medical education amid the COVID-19 pandemic. Indian Pediatr 2020;57:652-7. Tahrir MH, Borazjani R, Shirley R. COVID-19 and Iranian Medical Students; A Survey on Their Related-Knowledge, Preventive Behaviors and Risk Perception. Arch Iran Med 2020;23:249-54.

8. Modi PD, Nair G, Upper A, Modi J, Tuppekar B, Gharpure AS, et al. COVID19 awareness among healthcare students and professionals in Mumbai metropolitan region: A questionnairebased survey. Cureus 2020;12:e7514.

9. Chang J, Yuan Y, Wang D. Mental health status and its influencing factors among college students during the epidemic of COVID-19. Nan Fang Yi Ke Da Xue Xue Bao 2020;40:171-6. 
10. COVID-19Educational Disruption and Response. Available from: https://en.unesco.org/themes/educationemergencies/ coronavirus-schoolclosures.

11. Higher Education in India and COVID-19 Impact on Admission. Available from: https://home.kpmg/content/dam/kpmg/in/ pdf/2020/04/higher-education-in-indiaand-covid-19-impacton-admissions.pdf. 